Research, part of a Special Feature on Navigating Trade-offs: Working for Conservation and Development Outcomes

\title{
Will Forests Remain in the Face of Oil Palm Expansion? Simulating Change in Malinau, Indonesia
}

\author{
$\underline{\text { Marieke Sandker }}^{1}, \underline{\text { Aritta Suwarno }}^{1}$, and Bruce M. Campbell ${ }^{1,2}$
}

\begin{abstract}
The severe tensions between conservation and development are illustrated by events in Malinau Dstrict (Kalimantan, Indonesia). Conservationists decry proposed plans for logging and conversion of pristine tropical forest to oil palm (Elaeis guineensis). Although the local government is willing to declare the district a "conservation district," at the same time, it shows interest in oil palm conversion. This article explores the impact of the potential conversion of 500000 ha of forest to oil palm on forest cover, inmigration, and the local economy in Malinau. The simulation model was developed using STELLA® software, and relies on a combination of empirical data, data from the literature, and stakeholder perceptions. If a company were to clear the forest for timber without planting oil palm (as commonly happens), poverty levels are likely to rise rather than decline over the long term. If large-scale oil palm plantations were to be established, they could yield significant benefits to local authorities. However, such development would induce massive employment-driven migration, with wide-ranging consequences for the current inhabitants of the region. By visualizing and quantifying these trade-offs between conservation and development, the model stimulates debate and information exchange among conservationists, development actors, and district authorities so that well-informed choices can be made.
\end{abstract}

Key Words: Decentralization; district revenue; forest cover; landscape dynamics; livelihoods; oil palm; participatory model; primary forest

\section{INTRODUCTION}

Environmentalists worldwide are concerned about the conversion of pristine Indonesian rainforests to oil palm (Elaeis guineensis). Between 1980 and 2000, global palm oil production increased by $360 \%$ to 20.9 million tonnes in 2000 (Koh and Wilcove 2007) and it is forecast that global demand will double in the next 20 to 30 years (Sargeant 2001, Reinhardt et al. 2007). Mittermeier and Bowles (1993) consider the forests in Kalimantan to be one of the world's 15 tropical rainforest hotspots. Malinau is one of the newly designated districts in East Kalimantan Province, Indonesia (Fig. 1). Over $95 \%$ of the 4.3 million-ha area is still covered with forest (Badan Pusat Statistik (BPS) Malinau, unpublished data). The local authorities recognize its value and have declared Malinau a "conservation district" (one of only three in Indonesia), although at the same time, they have welcomed palm oil investments.
In June 2005, the Indonesian Minister of Agriculture revealed a government proposal for the world's largest oil palm plantation of 1.8 million ha along the Malaysia-Kalimantan border, cutting through three national parks. Campaigns and lobbying by civil society, Indonesian media and foreign diplomats forced the Indonesian government to revise its position on the mega-project but, although the Indonesian president acknowledges that conservation concerns should be considered, he continues to support oil palm development (Wakker 2006). This is understandable considering the role of palm oil in the Indonesian economy. In 2004, the export value of palm oil in Indonesia comprised US\$4.1 billion-or 1.7\% of the Indonesian gross national income (Koh and Wilcove 2007) - and roughly 4.5 million people rely on palm oil estates: 900000 people through direct employment and another 3.6 million through downstream processing, service industries, and remittances (Sargeant 2001). Susila (2004) found that oil palm activities 
Fig. 1. Geographical features of Malinau District (Source: Topografi Kodam (TOPDAM) 2004 and Badan Perencanaan Pembangunan Daerah (Bappeda) 2002).

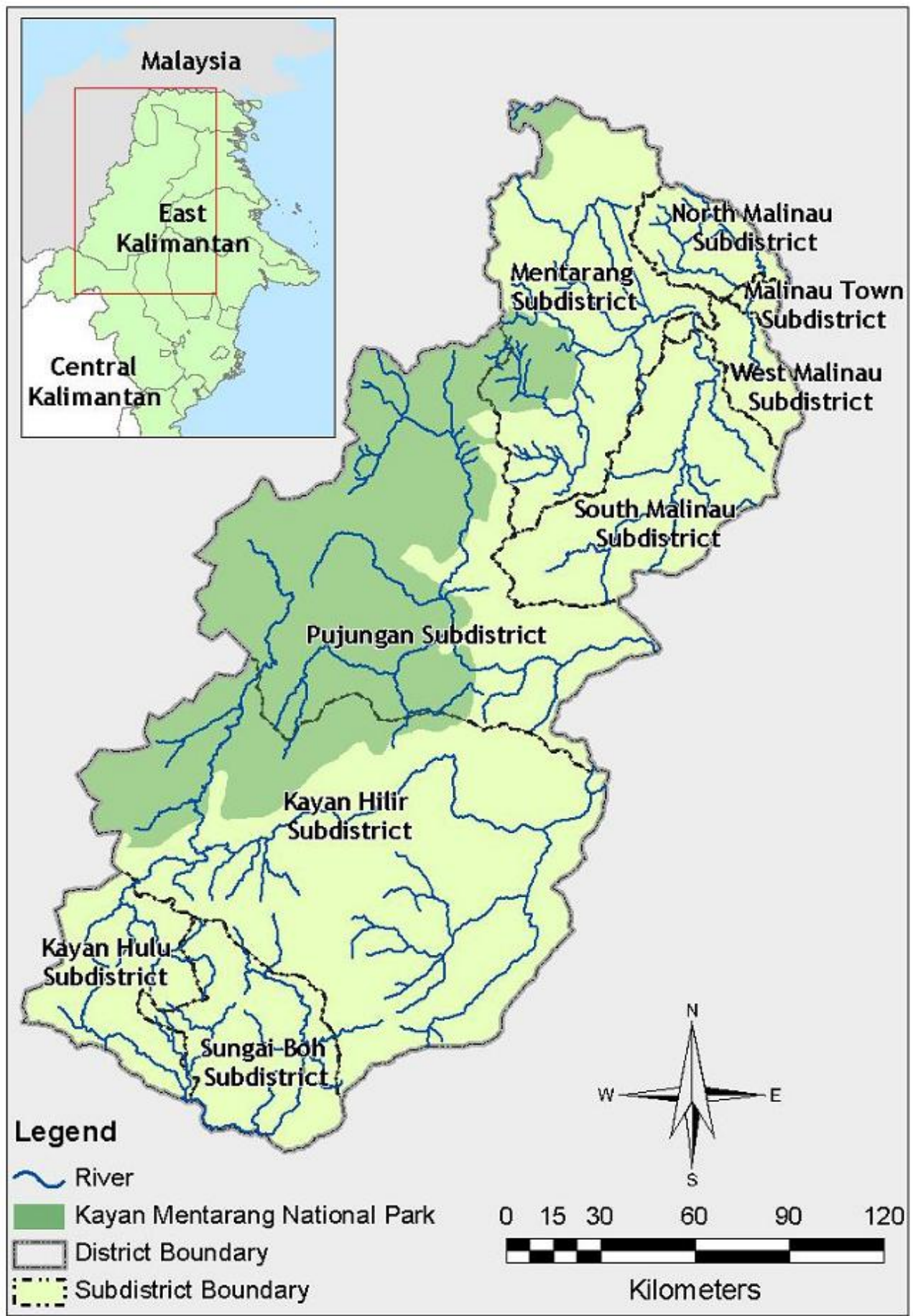


contribute 5-11 million IDR yearly or over $63 \%$ of smallholder household incomes in Kampar (Riau) and Musi Banyuasin (South Sumatra), and stated that the small proportion of poor people $(<10 \%)$ in oil palm communities in these sites is an indication of the commodities' contribution to poverty alleviation. Conservationists face big challenges given the monetary benefits of oil palm.

For Malinau, we examine the scenario of clearing 500000 ha of forest for oil palm and its consequences for local livelihood income, district revenue, and land-cover change. Given the employment created by such development, we also examine potential migration into Malinau. The aim of the paper is to simulate landscape dynamics in order to understand conservation and development trade-offs from the perspectives of different stakeholders.

\section{METHODS AND PROCESS}

Simulation models and participatory modeling can be useful in stimulating discussion about the future, and can contribute to decisions about complex landscapes (Sayer and Campbell et al. 2004). Sayer and Campbell (2004) argue for the use of exploratory or scoping (as opposed to predictive) models, with model building and outcomes stimulating discussion amongst different stakeholders who have different perspectives on the trade-offs between conservation and development. We stress that this is a scoping model, not a predictive model.

The scoping model was built using the dynamic, userfriendly modeling software STELLA® v.8 (High Performance Systems 1996). Initially, the elements for a model were shared with researchers from the Center of International Forestry Research (CIFOR) and a scoping model was produced that simulated land-cover change (Sayer and Campbell 2004, Lynam et al. 2003). The results of the early simulations were discussed with researchers and staff of the district, including the district head (Bupati). This gave the modelers feedback on priority issues, and the model was then further developed. A workshop was then convened with 12 representatives from the district agencies at which available information and data were shared and discussed. This was followed by smaller workshops and modeling training with those officials interested in pursuing the modeling. In early 2007, the results were presented to CIFOR researchers and generated much discussion. In late 2007, the scenario results were shared with district officials and the district head. More information on the modeling procedure can be found at: http://www.cifor.cgiar.org/conserv ation/ ref/home/index.htm.

The model includes variables covering land use, human populations, employment, forest and plantation economics, and district income. To identify the current status of livelihoods in Malinau district, we used data from the district statistical office (Badan Pusat Statistik, BPS) and data from CIFOR researchers working in Malinau between 2000 and 2007. All monetary values are reported in Indonesian Rupiah (IDR), where ca. US\$1 = IDR 9500. The sensitivity of the model's response to some key variables (income from agriculture, oil palm, and timber salaries, emigration and immigration rate) has been explored by changing their values $+/-20 \%$.

\section{LAND USE, LAND-USE SCENARIOS, AND LAND-COVER CHANGE}

\section{Main Land Use and Forest Types}

With decentralization in 1999, land-use allocation has come increasingly under the control of the district government, although allocation in the forestry service area is still legally under the central government. Conservation and protection forest form a large part of Malinau, dominated by the Kayan Mentarang National Park (Table 1). The forests in the non-forestry service area and "conversion" forest are forests allocated for conversion to other uses (e.g., agriculture, plantations).

For the model, we have divided forests into primary forest, logged-over primary forest, secondary forest, and degraded forest (Fig. 2). Degraded forest comprises <5-year-old bush fallow (following abandoned swidden cultivation) and land cleared for mining. Based on the district offices' documentation on shifting cultivation for the years 2002-2006 and on the mining area, degraded forest occupies about 16000 ha at the start of the simulation. Secondary forest comprises between 5and 40-year-old bush fallow and very intensely logged forest. The intensely logged forest is largely a consequence of large- and small-scale conversion permits-IPK and IPPK, respectively. Based on documentation in the district offices and estimation 
Table 1. Land-use allocation for Malinau (source: Dinas Kehutanan dan Perkebunan Kab. Malinau 2006, TGHK revised 2002 for mining area)

Land-use allocation 2006

Total Area, Malinau District

Non-Forestry Service land

Of which:

Mining concession (2002)

Currently under swidden agriculture (dryland paddy)

Currently under permanent agriculture (wetland paddy, crops, vegetables, fruits, and estate crops)

Forestry Service land

Of which:

Conversion forest

Production forest

Limited production forest (on steep slopes)

1280836

Protection forest (national park and forest reserves) of land under swidden cultivation over the period 1967-2002, secondary forest covers about 120000 ha at the start of the simulation.

Secondary forest $>40$ years old is categorized as logged-over primary forest, although under the oil palm simulations, we assume no secondary forest is converted to primary forest due to increased forest clearing. Roughly $20 \%$ of the landscape (about 950 000 ha) was logged by 2004 (logged-over primary forest). The remaining $75 \%$ of the landscape (about $3157000 \mathrm{ha}$ ) is categorized as primary forest at the start of the simulation.

\section{Logging and Conversion Permits}

With decentralization, district officials gained greater control over forest resources, often extending well beyond their official legal authority. They started issuing logging permits for small concessions (IPPK) in areas supposedly classified as conversion forest (Obidzinski and Barr 2003). There was minimal regulation of the subsequent logging. Barr et al. (2001:13) report on the enthusiasm of a palm oil company manager about the decentralization process stating, “...operations will be much smoother and more efficient if companies can deal straight with the Bupati."

A frequent practice observed in Indonesia is that IPK (permit for large-scale forest conversion) concession holders do the logging, but have no intention of converting the area into plantations. Of 2.5 million ha cleared for oil palm in East and West Kalimantan, only $20 \%$ had been planted by 2005 (Wakker 2006), with the remaining area thought to be cleared mainly for its timber. In the neighboring district Berau, the governor is under prosecution for "abuse of power" because, between 1999 and 2002, he issued a permit to plant a million hectares of oil palm, and the company that received the permit 
Fig. 2. Major land-use sectors captured in the model, showing the potential land-use transformations.

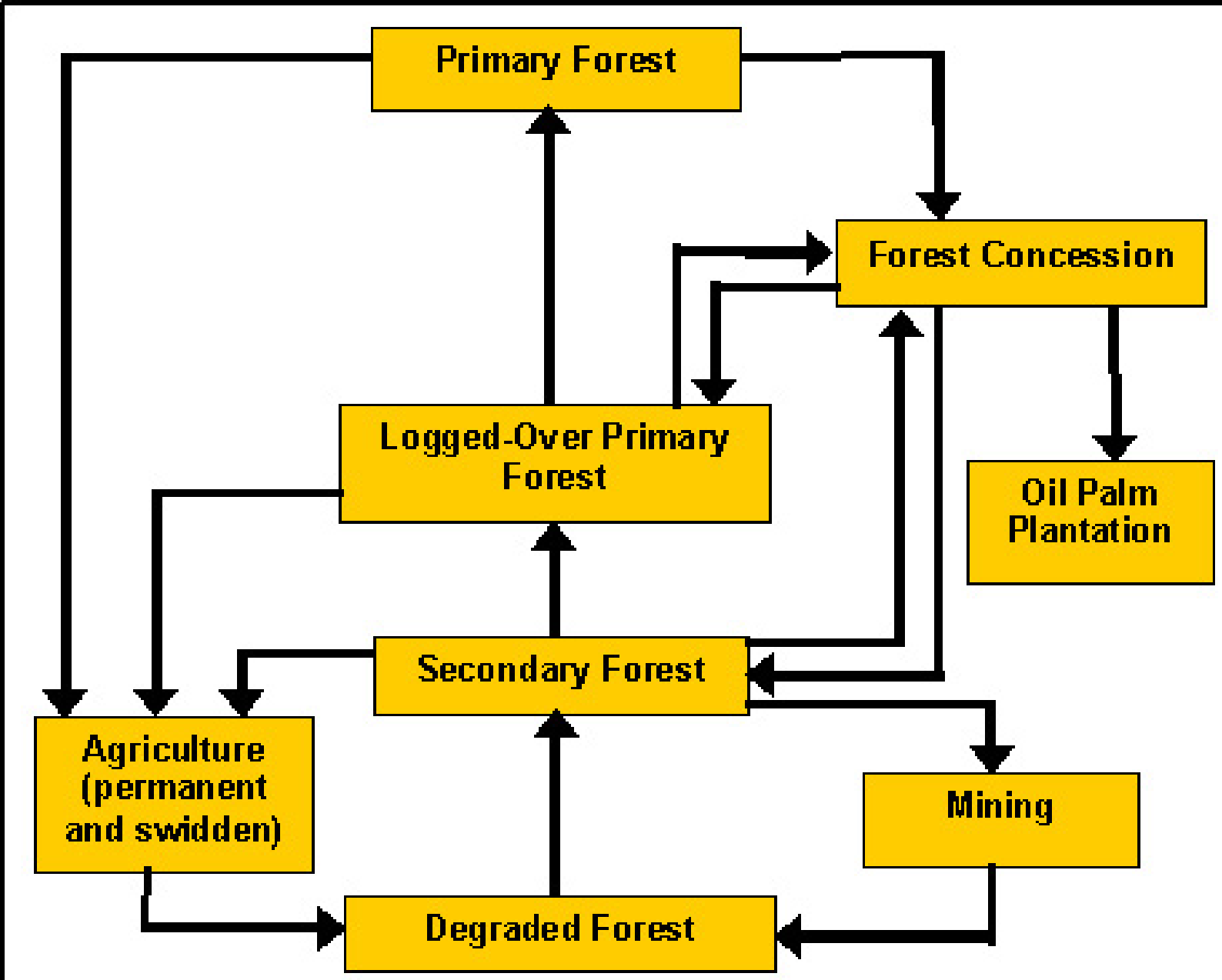

cleared the land, made use of the wood, but never planted oil palm (Castaño 2006). In Malinau, there have also been major proposals for oil palm where land is regarded as not suitable for oil palm, being remote, very steep, and with infertile soils (Basuki and Sheil 2005, Lynam et al. 2006), leading to the belief that the proposed development of oil palm is a guise for timber harvesting. Neighboring districts closer to the sea with extended lowlands would be more cost-effective investments for oil palm in the short term. However, the road network is rapidly expanding, with new roads now linking Malinau to Nunukan and Bulungan districts, so markets are effectively becoming more accessible and oil palm investments more likely to happen, although some believe that the land capacity is such that oil palm will not be economically viable (Basuki and Sheil 2005).

\section{Oil Palm Scenarios}

Currently there are no plantations in Malinau. In our simulation, we assume the development of oil palm will start in 5 years' time (2012). To explore the potential future impact of oil palm development, we have used four scenarios: 
1. No oil palm development (as at present);

2. Forest clearing, but no oil palm planted (as has occurred elsewhere);

3. Forest clearing and oil palm plantation, assuming low employment rates, and

4. Forest clearing and oil palm plantatin, assuming high employment rates.

In all scenarios, HPH/IUPHHK logging (largescale concessions using less intensive logging) occurs throughout the simulation, starting with current levels and increasing by $50 \%$ toward the end of the simulation.

In scenarios 2-4, five logging permits for forest conversion are issued for an area of 100000 ha each. Permits for plantation production are usually given for a 25- to 30-year period, and after that, they can be extended or terminated. The timber clearing through IPK permits in scenarios 2-4 is assumed to take place over a period of 20 years (from 20122032 in the simulation), increasing in intensity over time (too few workers and equipment are available in the first years). Thus, after 25 years, 500000 ha of forest will be cleared.

Under scenario 2, we simulate "timber speculators," who do intensive logging in primary logged-over forest, converting it to secondary forest. We assume that they mainly use the non-forestry service area and the area allocated as conversion forest (Table 1) although there will be some use of the permanent forest domain (about 70000 ha). Furthermore, we assume that the company gives logging jobs to migrants only, and only pays a minimum compensation fee of IDR $5000 / \mathrm{m}^{3}$ to villages (see below).

In scenarios 3 and 4, we simulate more responsible companies that plant the full 500000 ha, $40 \%$ from secondary forest and $60 \%$ from primary loggedover forest, all of which is non-forestry service area and conversion forest. We assume the plantations are largely located in lowlands closer to transport routes (e.g., close to Malinau town). Scenario 3 assumes an employment of 0.1 jobs per ha of oil palm, which corresponds to current employment figures in Malaysian oil palm plantations (van Noordwijk, pers. comm. 2007). Scenario 4 assumes an average of 0.2 jobs per ha of oil palm, corresponding with Indonesian contexts (Sargeant
2001). It is assumed villages get a fee of 20000 $\mathrm{IDR} / \mathrm{m}^{3}$ for the timber removed.

The timber compensation fees of IDR 5000-20 000/ $\mathrm{m}^{3}$ are a low to moderate estimate as Palmer (2004) mentions that fees can go up to IDR $50000 / \mathrm{m}^{3}$, and Barr et al. (2001) measured up to IDR 30000 IDR/ $\mathrm{m}^{3}$. The IDR 5000 fee follows an example in Malinau mentioned by Barr et al. (2001: 32).

\section{Agriculture}

For many years, livelihoods in Malinau district have been dominated by agriculture, hunting, and gathering. Of the local population, about $75 \%$ live outside the district capital, with the majority being swidden cultivators. A few are hunter-gatherers, but at least $80 \%-85 \%$ of these Punan households undertake farming (Levang et al. 2005). Despite the prevalence of agriculture, its formal contribution to the district's economy was only 6\% in 2002 (BPS 2003 in Andrianto 2006). The population sub-model drives the rate of increase or decrease in farming households, and this feeds directly to the area farmed. A slight shift from jobs in agriculture to jobs in the service and trade industry is modeled as a result of urbanization.

We distinguish between permanent and swidden cultivation (Table 1). The former is intensive crop and tree production. Swidden cultivation is prevalent. It starts with the conversion of loggedover primary forest to dryland rice cultivation. After about 2 years, when crop yields are low and weed infestation increases, farmers abandon the field and it becomes bush fallow. At the moment, the pressure on the land is so low that bush fallow is left to grow into secondary forest, which is only turned into swidden fields again when it is very old and resembles primary forest. However, under the oil palm scenario, primary and old secondary forest in the vicinity of the villages will become scarce, and thus, farmers will be forced to reduce the fallow period, which will result in higher levels of weed infestation and lower per hectare swidden yields (modeled to drop by $30 \%$ ).

\section{Mining}

A small portion of the landscape is allocated to coal mining (Table 1), but of that, only about $30 \%$ has been mined. Recently mining activities ceased 
because of the costs of extraction. It is difficult to predict future mining activities, but given the high transport costs in Malinau, we have assumed only a small annual increase in the area mined (e.g., from 1000 to about $2000 \mathrm{ha} /$ year under scenario 4). This increase is due to population increase, where a proportion of the unemployed commence artisanal mining.

\section{Forest Products}

People in Malinau depend heavily on forest products for their livelihoods. Levang et al. (2005) found that $72 \%$ of the local Punan people collect forest products, but only $16 \%$ rely on it for their main cash income. Their study shows that the mean annual income of a Punan household from agriculture is IDR 1.67-2.25 million, whereas that from forest products is IDR 1.72-4.56 million, depending on the remoteness of the villages. These figures apply better to the more remote huntergatherer communities. According to Pambudhi et al. (2004), oil palm and pulp plantations often displace villagers and their rattan gardens. An increase in IPK logging and plantations is assumed, in the model, to result in decreased availability of non-timber forest products (NTFPs). We assume in the model that about $70 \%$ of local people are involved in forest product collection, but that only $10 \%$ of migrants collect forest products.

\section{Simulated Land-cover Changes}

Under the no plantation development scenario, we assume that the current secondary forest (about 120 000 ha) can grow into primary logged-over forest during the simulation, whereas under the other scenarios, we assume no such land-cover change because of the high pressure on the forest. Without plantation development, there is a loss of only about $5 \%$ of primary and primary logged-over forest over 40 years, largely as a result of on-going small-scale agriculture (Fig. 3). The simulations where forest conversion permits are issued (2-4) suggest a loss of about $20 \%$ of the primary and primary loggedover forest over 40 years.

Agriculture comprises a very small part of the landscape initially because of the low population numbers and the low commercial demand for agricultural products. With the forest clearance scenarios, agricultural area increases 4.5 to 11 times (scenario 2 and 4, respectively), because of expanding populations (see next section). As land will become scarce in the legally available area, between 200000 and 360000 ha of forest in the permanent forest domain will be converted into agriculture under scenarios 2, 3, and 4. Degraded forest covers 16000 ha at the start of the simulation, but this expands to about $60000,85000,100000$, and 140000 ha in scenarios 1, 2, 3, and 4, respectively, mainly as a result of the increase in bush fallow.

Fire is not included in the model, and has not been a feature of Malinau. As such, the amount of forest lost could be underestimated in the oil palm scenarios. Fire is a significant threat in other parts of Indonesia, and forest concessionaires and those seeking to establish tree crop plantations are considered major contributors to fire frequency (Gönner 2000, Food and Agriculture Organization (FAO) 2003). Once fire enters the system, it may remain as a permanent feature (du Toit et al. 2004). The Department of Forestry and Plantations (1998, in Casson 2000) holds oil palm expansion partly responsible for the 1997-1998 forest and land fires that affected more than 5 million ha of forest in Kalimantan.

\section{ECONOMIC DEVELOPMENT}

\section{Population Numbers}

The total population in Malinau district was 59212 in 2006 (BPS Malinau, unpublished data) and has increased by $6.5 \%$ yearly over the last 8 years (cf. Bappeda Tk II Bulungan 1998 in Barr et al. 2001; BPS Malinau, unpublished data). This high annual rate of increase is mainly caused by in-migration related to new economic opportunities. The average increase in the urban Malinau sub-district was $8.5 \%-9 \%$ compared with $3 \%$ in the rural subdistricts. The model simulates natural growth and in-migration, and differentiates between local people and transmigrants. CIFOR researchers estimate that of the 59212 in the district about 7000 are immigrants, most living in Malinau town and some in Long Loreh, where the mining company was active. In-migration in the model is largely driven by jobs in IPK logging and oil palm plantations, where we assume that three people immigrate for each new job filled by a migrant, causing the migrant population to rise sharply with plantation development scenarios (Fig. 4). The total 
Fig. 3. A 40-year simulation of land cover in Malinau district: (a) Scenario 1, No clearing permit given out; (b) Scenario 2, Forest clearing without oil palm planted; (c) Scenario 4, Plantation development (high employment).
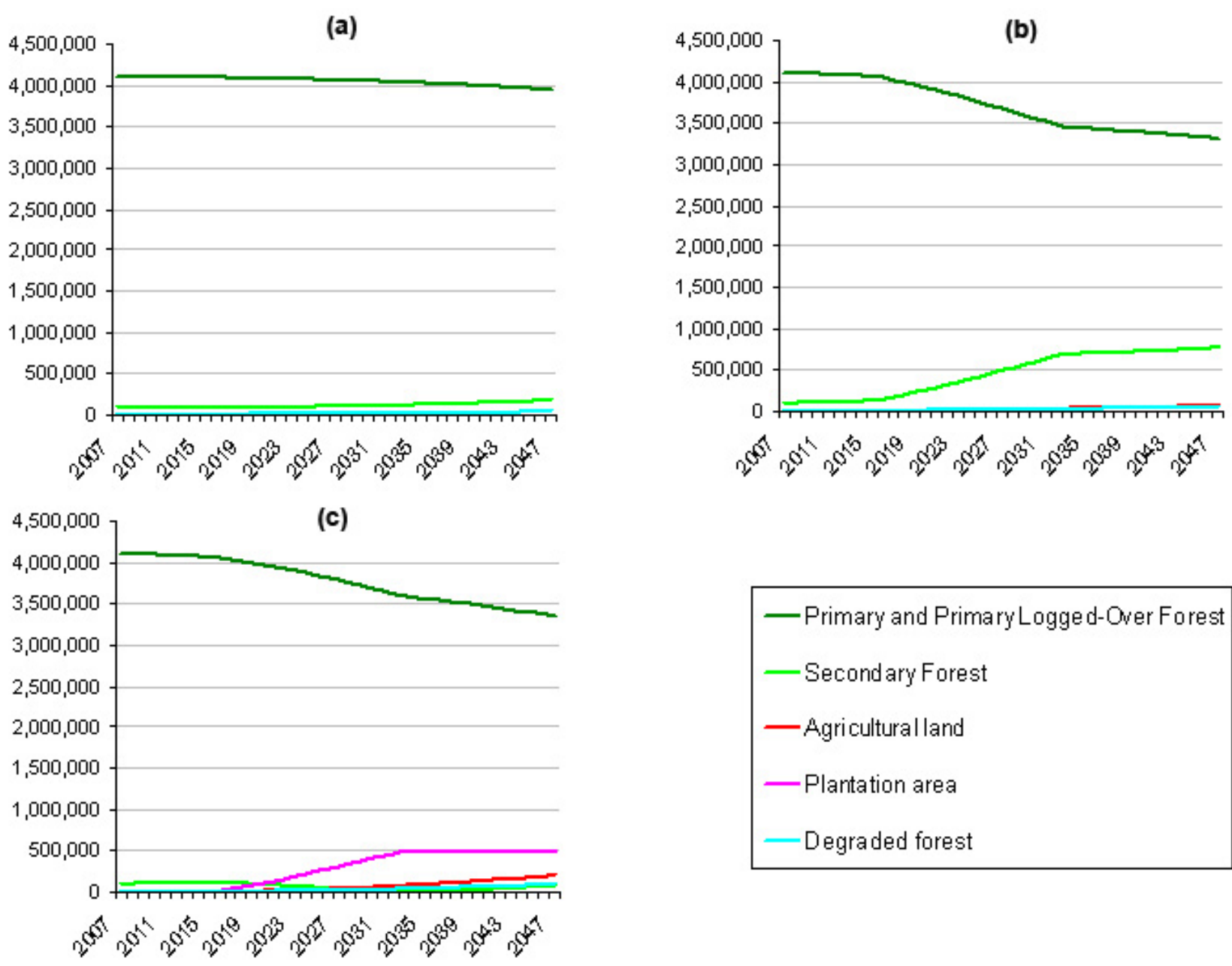

- Primary and Primary Logged-Over Forest

- Secondary Forest

-Agricultural land

-Plantation area

-Degraded forest population in Malinau under the plantation development scenario will increase by 4.7 (scenario 2) to 13.5 times (scenario 4 ) after 40 years. After year 2027 of the simulation, the employment drops because of the sharp decrease in timber jobs (2027) when IPK logging stops. For the model, we assume that, where migrant employment drops under $35 \%$ (meaning less than 35\% of employable migrants are employed), this results in out-migration rates as high as $2 \%$. Under scenario 4 , the now modest number of 7000 migrants will increase by a factor of 80 after 40 years. Although the local Dayak people are currently in the majority, they will be a minority if 500000 ha are planted with oil palm.

\section{Financial Compensation from Logging Companies to Local Communities}

Decentralization not only resulted in district governments securing a greater share of forestry revenues, but also had implications for local communities. A 2000 law entitles communities to 
Fig. 4. A 40-year simulation of total local population (blue lines) and migrant population (red lines) in Malinau district, under the four different scenarios ( $1=$ no plantation; $2=$ IPK clearing without plantation development; 3 = plantation development assuming low employment; and 4 = plantation development assuming high employment.

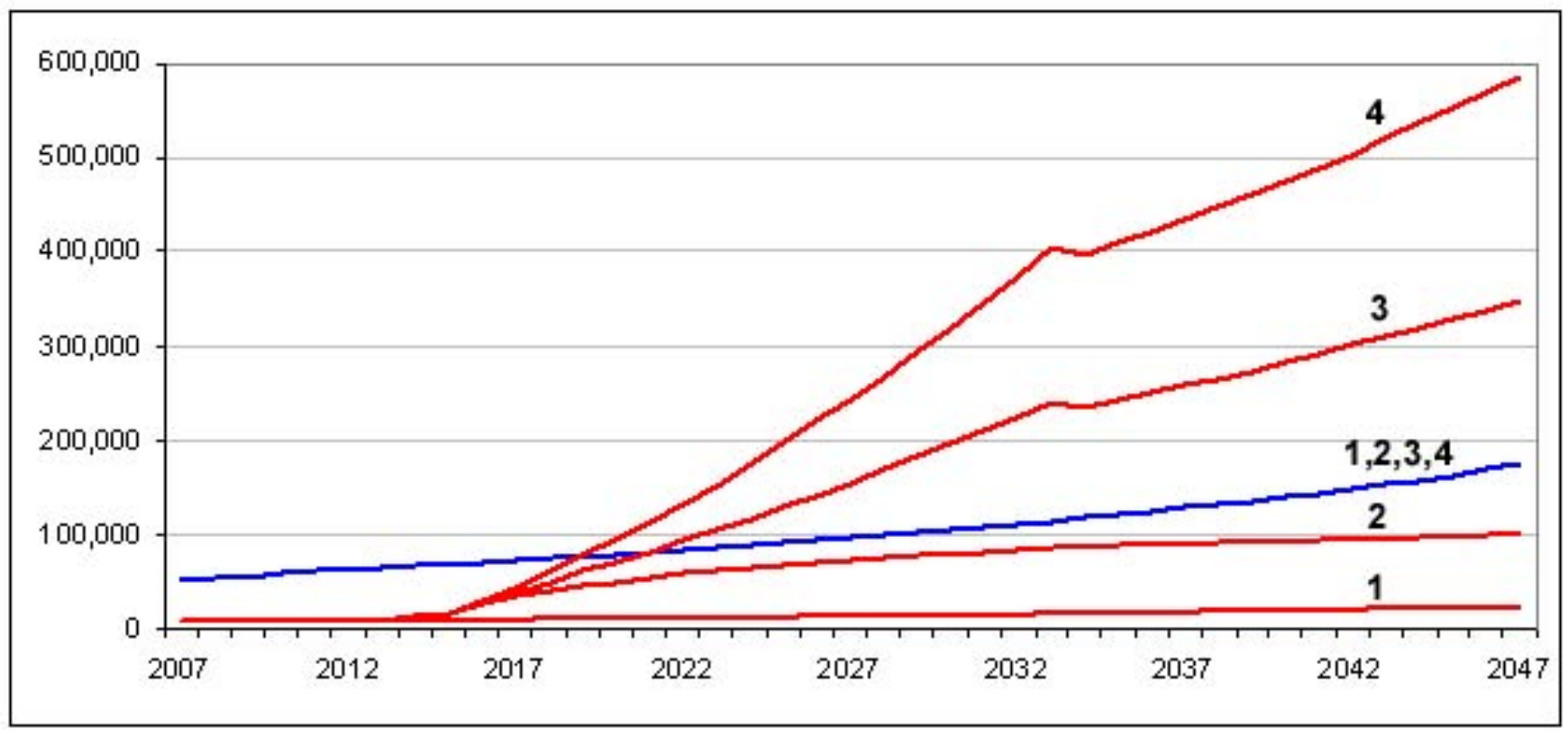

demand compensation for timber harvesting from concession holders, although this law is open to dispute because of weak enforcement of property rights (Engel et al. 2006). Andrianto (2006) records greater conflicts among communities, and environmental degradation following the implementation of the new regulations regarding logging, and he concludes that, in West-Kutai and Malinau districts, the policies have failed to increase the standard of living of poor communities. On the contrary, Palmer (2004) states decentralization has undoubtedly led to higher capture of logging rents by the Sekatak community in Malinau. Palmer (2004) and Barr et al. (2001) indicate mixed outcomes from local negotiations, Barr et al. (2001:30) noting that many agreements are "absurd or have been unfulfilled." Palmer (2004) mentions IPPK fees of around IDR $50000 / \mathrm{m}^{3}$ of timber going to local communities. Although this is low, it is five times more than those paid by the large logging companies that dominated the logging industry before decentralization.

\section{Household Income}

At the start of the simulation, the percentage of households was highest in the agricultural sector $(76 \%)$ (Table 2). With the exception of scenario 4 , agriculture remains the most important sector throughout the simulations, although under scenarios 2-4, the number of households in the timber sector increases more than tenfold after 20 years (mainly because of IPK). In 2027, the most substantial number of households will be active in the oil palm sector in scenarios 3 and 4 , although by 2047, this will have shifted to the agriculture and the trade and services sectors because the number of jobs in the oil palm sector does not continue to increase after 25 years even though the population does. The creation of employment in the region is substantial under the oil palm scenario, even when a low employment rate in oil palm plantations is used. With scenario 1 , the total number of formal jobs available (in mining, timber and civil service) does not exceed 10000 . In the other scenarios, the number of formal jobs reaches as high as 22000 
(scenario 2), 71000 (scenario 3), and 120000 (scenario 4).

The significant amount of income generated by employment in oil palm in year 2027 under scenarios 3 and 4 is shown in Table 3 . There are also associated expansions in other sectors, driven by the plantation economy. The income from agriculture increases substantially, for example. With an increase in employment, we assume a high demand for agricultural products and roads opening up the area improve market access. Where most of current production is for auto-consumption, we expect an increase in permanent agriculture and the demise (in proportionate terms) of swidden cultivation.

Levang et al. (2005) undertook household surveys, sampling 254 Punan households in six different settlements in Malinau and neighboring districts. They found $83 \%$ of the sampled households live under the US\$1/day poverty line. Average household incomes are improved under the oil palm scenarios ( 3 and 4 ), increasing by $60 \%-150 \%$, but increasing $<10 \%$ in scenario 1 without oil palm (Table 3, last row). Household incomes are also raised with forest clearing without oil palm (scenario 2) after 20 years, but once forest clearing stops, the average incomes decline, and after 40 years, average household incomes are lower than when no IPK forest clearing had occurred (scenario $1)$.

The above figures hide the differentiation between local and migrant households. The activity portfolio differs substantially for migrant and local households. Migrants are currently largely urban, with a high percentage of households active in the trade and service industries (Table 4). Jobs in the timber and plantation sector typically go to migrants, who often have higher schooling levels. Local people, however, are currently given priority for all jobs in the civil service, and they are the ones receiving compensation fees for logging (Table 4). Local people receive short-term benefits from scenario 2 (2027), with more commercialized agriculture, more civil service jobs, and timber fees. After 40 years, however, they are left with hardly any forest in proximity to their villages, reducing their income from forest products and shortening their fallow periods in shifting cultivation, and consequently lowering their yields. Migrants will receive most of the short-term benefits, getting most jobs in IPK forest clearing. After 40 years, the high unemployment for migrants will cause some outmigration, although most are expected to remain; a portion will buy a piece of agricultural land and start farming for much lower earnings. This scenario is expected to cause high levels of conflict.

Scenarios 3 and 4 improve incomes for both local people as well as migrants. Local people's incomes increase most in year 2027 when timber fees increase $>20$ times (scenario 4 in Table 3 ), and drop thereafter when IPK logging ends. Local household incomes remain 30\%-65\% higher than under scenario 1 at the end of the simulation, mostly because of commercialization of agriculture, although jobs in the civil service, trade, and the service industry also contribute to higher incomes (Table 4a). Migrants' incomes are also highest in year 2027 because of jobs in IPK logging (Table 4b). After the sharp decline in IPK employment, some of the migrants will obtain employment on the plantations and some will buy some land for agriculture. Although incomes may have increased under oil palm development, overall well-being is more difficult to judge. Koczberski et al. (2001) and Casson (2000) report cases of local resentment ove benefits from oil palm plantations going to outsiders. Colchester et al. (2006) give examples of increased social and financial costs with oil palm arrival. For example, there were social costs of resolving conflicts over land and benefit sharing associated with oil palm estates. Air quality declined, and there was a worrying increase in alcohol abuse in local communities. More research is needed on the negative and positive impacts on local people of oil palm plantations.

\section{District Development}

Since Malinau was declared a new district in 1999, district income has increased dramatically from only IDR 5.8 billion in 2000 (Barr et al. 2001) to IDR 405 billion and IDR 615 billion in 2002 and 2003, respectively (Andrianto 2006). Using per ha and per $\mathrm{m}^{3}$ payments applied to IPPK in Malinau (Barr et al. 2001), the issuance of IPK permits for the clearance of 500000 ha forest will provide the district with a cumulative income of IDR 703 billion over 20 years. Under scenarios 3 and 4 , an additional IDR 102 billion is provided over the 40-year simulation by oil palm production fees. However, the district income will increase by more than these fees alone, as the increased economic activity is 
Table 2. Employment in different sectors (number of households per sector), and total population in Malinau district

\begin{tabular}{|c|c|c|c|c|c|c|c|c|c|}
\hline \multirow[b]{4}{*}{$\begin{array}{l}\text { Primary a- } \\
\text { ctivities of } \\
\text { households: }\end{array}$} & \multicolumn{9}{|c|}{ No. of Households ${ }^{\dagger}$} \\
\hline & \multirow{3}{*}{$\begin{array}{l}\text { Start } \\
2007\end{array}$} & \multicolumn{8}{|c|}{ Simulation results } \\
\hline & & \multicolumn{2}{|l|}{2027} & \multicolumn{4}{|c|}{2047} & & \\
\hline & & $\begin{array}{r}\text { 1. No } \\
\text { plantation } \\
\text { development }\end{array}$ & $\begin{array}{l}\text { 2. Forest } \\
\text { clearing } \\
\text { without oil } \\
\text { palm plan- } \\
\text { ting }\end{array}$ & $\begin{array}{r}\text { 3. Plantation } \\
\text { development } \\
\text { with } 0.1 \\
\text { jobs/ha }\end{array}$ & $\begin{array}{r}\text { 4. Plantation } \\
\text { development } \\
\text { with } 0.2 \\
\text { jobs/ha }\end{array}$ & $\begin{array}{r}\text { 1. No } \\
\text { plantation } \\
\text { development }\end{array}$ & $\begin{array}{l}\text { 2. Forest } \\
\text { clearing } \\
\text { without oil } \\
\text { palm plan- } \\
\text { ting }\end{array}$ & $\begin{array}{r}\text { 3. Plantation } \\
\text { development } \\
\text { with } 0.1 \\
\text { jobs/ha }\end{array}$ & $\begin{array}{r}\text { 4. Plantation } \\
\text { development } \\
\text { with } 0.2 \\
\text { jobs/ha }\end{array}$ \\
\hline $\begin{array}{l}\text { Agriculture } \\
\text { and NTFPs }\end{array}$ & 9900 & 17700 & 21800 & 24700 & 28500 & 31500 & 43000 & 54800 & 76600 \\
\hline $\begin{array}{l}\text { Timber C- } \\
\text { oncession }\end{array}$ & 1000 & 1200 & 11100 & 11100 & 11100 & 1500 & 1500 & 1500 & 1500 \\
\hline Plantation & 0 & 0 & 0 & 21100 & 42200 & 0 & 0 & 31600 & 63200 \\
\hline Mining & 200 & 300 & 300 & 300 & 300 & 500 & 500 & 500 & 800 \\
\hline $\begin{array}{l}\text { Gov. offic- } \\
\text { ials and } \\
\text { civil serva- } \\
\text { nts }\end{array}$ & 1300 & 2400 & 3500 & 4200 & 5300 & 3700 & 4300 & 6200 & 9800 \\
\hline $\begin{array}{l}\text { Trade and } \\
\text { service in- } \\
\text { dustries }\end{array}$ & 1400 & 4300 & 8900 & 15400 & 22400 & 11300 & 18300 & 35200 & 58700 \\
\hline \multirow{3}{*}{$\begin{array}{l}\text { Total hou- } \\
\text { seholds }\end{array}$} & 12900 & 23300 & 35700 & 53500 & 72500 & 42200 & 58000 & 95900 & 148400 \\
\hline & \multicolumn{2}{|c|}{ Total population } & & & & & & & \\
\hline & 60000 & 108600 & 166300 & 249200 & 338100 & 196500 & 270200 & 446700 & 691500 \\
\hline $\begin{array}{l}\dagger \text { Average } \\
\text { agricultur } \\
+ \text { The tota } \\
\text { household }\end{array}$ & $\begin{array}{l}\text { e numbers } \\
\text { al of house } \\
\text { ds are invo }\end{array}$ & $\begin{array}{l}\text { of workers } \\
\text { ing and tra } \\
\text { holds invo } \\
\text { lved in mo }\end{array}$ & $\begin{array}{l}\text { s per hous } \\
\text { de }-1 \text {; tin } \\
\text { lved per a } \\
\text { re than on }\end{array}$ & $\begin{array}{l}\text { ehold for th } \\
\text { nber plantat } \\
\text { activity can } \\
\text { ne activity. }\end{array}$ & $\begin{array}{l}\text { he specifie } \\
\text { tion and } c \\
\text { be higher }\end{array}$ & $\begin{array}{l}\text { ed sectors } \\
\text { thivil servic } \\
\text { than the to }\end{array}$ & $\begin{array}{l}\text { are assume } \\
\text { ce }-1.5 \text { wo } \\
\text { otal housel }\end{array}$ & $\begin{array}{l}\text { ed to be as } \\
\text { orkers per h } \\
\text { holds becau }\end{array}$ & $\begin{array}{l}\text { follows: } \\
\text { household. } \\
\text { use some }\end{array}$ \\
\hline
\end{tabular}


Table 3. Total income (in billions IDR) per sector for all households in Malinau, with the last row showing averages per household

\begin{tabular}{|c|c|c|c|c|c|c|c|c|c|}
\hline \multirow[b]{2}{*}{$\begin{array}{l}\text { Primary a- } \\
\text { ctivities of } \\
\text { households: }\end{array}$} & \multirow[b]{2}{*}{$\begin{array}{r}\text { Start of } \\
\text { simulation } \\
(2007)\end{array}$} & \multicolumn{4}{|c|}{ Simulation results -2027} & \multicolumn{4}{|c|}{ Simulation results - 2047} \\
\hline & & $\begin{array}{r}1 . \text { No } \\
\text { plantation }\end{array}$ & $\begin{array}{l}\text { 2. Forest } \\
\text { clearing } \\
\text { without oil } \\
\text { palm plan- } \\
\text { ting }\end{array}$ & $\begin{array}{r}\text { 3. Plantation } \\
\text { development } \\
\text { with } 0.1 \\
\text { jobs/ha }\end{array}$ & $\begin{array}{l}\text { 4. Plantation } \\
\text { development } \\
\text { with } 0.2 \\
\text { jobs } / \text { ha }\end{array}$ & $\begin{array}{r}1 . \text { No } \\
\text { plantation }\end{array}$ & $\begin{array}{l}\text { 2. Forest } \\
\text { clearing } \\
\text { without oil } \\
\text { palm plan- } \\
\text { ting }\end{array}$ & $\begin{array}{r}\text { 3. Plantation } \\
\text { development } \\
\text { with } 0.1 \\
\text { jobs/ha }\end{array}$ & $\begin{array}{r}\text { 4. Plantation } \\
\text { development } \\
\text { with } 0.2 \\
\text { jobs } / \text { ha }\end{array}$ \\
\hline Agriculture & 27 & 51 & 89 & 155 & 245 & 93 & 131 & 382 & 845 \\
\hline $\begin{array}{l}\text { Forest Pro- } \\
\text { ducts }\end{array}$ & 26 & 45 & 21 & 38 & 36 & 76 & 0 & 17 & 15 \\
\hline $\begin{array}{l}\text { Timber co- } \\
\text { ncessions }\end{array}$ & 13 & 16 & 165 & 162 & 162 & 20 & 20 & 20 & 20 \\
\hline Plantation & 0 & 0 & 0 & 300 & 600 & 0 & 0 & 449 & 899 \\
\hline Mining & 0.2 & 0.3 & 0.3 & 0.2 & 0.3 & 0.4 & 0.5 & 0.5 & 0.7 \\
\hline $\begin{array}{l}\text { Gov. offic- } \\
\text { ials and } \\
\text { civil service }\end{array}$ & 24 & 44 & 66 & 79 & 98 & 68 & 79 & 115 & 181 \\
\hline $\begin{array}{l}\text { Trade and } \\
\text { service in- } \\
\text { dustries }\end{array}$ & 16 & 48 & 130 & 248 & 374 & 122 & 249 & 553 & 975 \\
\hline Timber fees & 2.5 & 3.0 & 15.4 & 52.6 & 52.6 & 3.7 & 3.7 & 3.7 & 3.7 \\
\hline Total & 109 & 207 & 485 & 1034 & 1569 & 383 & 483 & 1540 & 2939 \\
\hline $\begin{array}{l}\text { Average per } \\
\text { hh } \\
\text { (in millions } \\
\text { IDR) }\end{array}$ & 8.5 & 8.9 & 13.6 & 19.3 & 21.6 & 9.1 & 8.3 & 16.1 & 19.8 \\
\hline
\end{tabular}

expected to substantially augment tax payments in the district. The simulated additional tax payments over 40 years for scenarios 2-4 are IDR 22 billion, IDR 149 billion, and IDR 276 billion, respectively.

\section{DISCUSSION}

\section{Are Payments for Environmental Services a Viable Economic Option for the District?}

Given the economic attractiveness of the oil palm development scenario to district and national government stakeholders, as well as to key local people (e.g., those who may benefit from land sales or various illegal transactions), the question is whether conservationists have alternative development scenarios. Much is made of direct payments for environmental services (PES) (Ferraro and Kiss 2002), and one could argue that the global community interested in biodiversity could change the incentive structure for local and district stakeholders by paying for biodiversity services provided by Malinau. However, the area is vast and the size of payments (needed to get household income increases similar to those offered by the oil 
Table 4. Average annual cash income (millions IDR) for (a) local households, and (b) migrant households; and percentage contribution of each activity to annual income, under four different scenarios

\begin{tabular}{|c|c|c|c|c|c|c|c|c|c|}
\hline \multirow[b]{2}{*}{ (a) Local households } & \multirow[b]{2}{*}{$\begin{array}{r}\text { Start of } \\
\text { simulation } \\
(2007)\end{array}$} & \multicolumn{4}{|c|}{ Simulation results -2027} & \multicolumn{4}{|c|}{ Simulation results -2047} \\
\hline & & $\begin{array}{r}1 . \text { No } \\
\text { plantation }\end{array}$ & $\begin{array}{l}\text { 2. Forest } \\
\text { clearing wi- } \\
\text { thout oil } \\
\text { palm planting }\end{array}$ & $\begin{array}{r}\text { 3. Planta- } \\
\text { tion dev- } \\
\text { elopment } \\
\text { with } 0.1 \\
\text { jobs/ha }\end{array}$ & $\begin{array}{l}\text { 4. Planta- } \\
\text { tion dev- } \\
\text { elopment } \\
\text { with } 0.2 \\
\text { jobs/ha }\end{array}$ & $\begin{array}{r}1 . \text { No } \\
\text { plantation }\end{array}$ & $\begin{array}{l}\text { 2. Forest } \\
\text { clearing wi- } \\
\text { thout oil } \\
\text { palm planting }\end{array}$ & $\begin{array}{r}\text { 3. Plantation } \\
\text { developm- } \\
\text { ent with } \\
0.1 \text { jobs/ } \\
\text { ha }\end{array}$ & $\begin{array}{r}\text { 4. Plantation } \\
\text { development } \\
\text { with } 0.2 \\
\text { jobs/ha }\end{array}$ \\
\hline $\begin{array}{l}\text { Average annual hh } \\
\text { income } \\
\text { (in millions IDR) }\end{array}$ & 7.8 & 8.2 & 9.3 & 14.6 & 16.6 & 8.4 & 6.7 & 10.7 & 13.8 \\
\hline \multicolumn{10}{|l|}{ Share from: } \\
\hline Agriculture & $28 \%$ & $27 \%$ & $32 \%$ & $27 \%$ & $28 \%$ & $27 \%$ & $34 \%$ & $41 \%$ & $43 \%$ \\
\hline Forest products & $29 \%$ & $26 \%$ & $10 \%$ & $11 \%$ & $9 \%$ & $24 \%$ & $0 \%$ & $4 \%$ & $2 \%$ \\
\hline $\begin{array}{l}\text { Timber, plantation, } \\
\text { and mining jobs }\end{array}$ & $7 \%$ & $4 \%$ & $4 \%$ & $15 \%$ & $20 \%$ & $3 \%$ & $4 \%$ & $12 \%$ & $17 \%$ \\
\hline Civil service jobs & $24 \%$ & $23 \%$ & $31 \%$ & $19 \%$ & $19 \%$ & $20 \%$ & $29 \%$ & $21 \%$ & $21 \%$ \\
\hline Trade and service & $9 \%$ & $17 \%$ & $15 \%$ & $10 \%$ & $9 \%$ & $26 \%$ & $33 \%$ & $21 \%$ & $16 \%$ \\
\hline Timber fees & $3 \%$ & $2 \%$ & $8 \%$ & $18 \%$ & $15 \%$ & $1 \%$ & $1 \%$ & $1 \%$ & $1 \%$ \\
\hline
\end{tabular}

\begin{tabular}{|c|c|c|c|c|c|c|c|c|c|}
\hline \multirow[b]{2}{*}{$\begin{array}{l}\text { (b) Migrant } \\
\text { households }\end{array}$} & \multirow[b]{2}{*}{$\begin{array}{r}\text { Start of } \\
\text { simulation } \\
(2007)\end{array}$} & \multicolumn{4}{|c|}{ Simulation results -2027} & \multicolumn{4}{|c|}{ Simulation results -2047} \\
\hline & & $\begin{array}{r}1 . \text { No } \\
\text { plantation }\end{array}$ & $\begin{array}{r}\text { 2. Forest } \\
\text { clearing wit- } \\
\text { hout oil } \\
\text { palm planting }\end{array}$ & $\begin{array}{l}\text { 3. Planta- } \\
\text { tion dev- } \\
\text { elopment } \\
\text { with } 0.1 \\
\text { jobs/ha }\end{array}$ & $\begin{array}{l}\text { 4. Planta- } \\
\text { tion dev- } \\
\text { elopment } \\
\text { with } 0.2 \\
\text { jobs/ha }\end{array}$ & $\begin{array}{r}1 . \text { No } \\
\text { plantation }\end{array}$ & $\begin{array}{r}\text { 2. Forest } \\
\text { clearing w- } \\
\text { ithout oil } \\
\text { palm plan- } \\
\text { ting }\end{array}$ & $\begin{array}{l}\text { 3. Planta- } \\
\text { tion dev- } \\
\text { elopment } \\
\text { with } 0.1 \\
\text { jobs/ha }\end{array}$ & $\begin{array}{r}\text { 4. Plantation } \\
\text { development } \\
\text { with } 0.2 \\
\text { jobs/ha }\end{array}$ \\
\hline $\begin{array}{l}\text { Average annual hh } \\
\text { income } \\
\text { (in millions IDR) }\end{array}$ & 13.8 & 13.6 & 19.4 & 22.3 & 23.6 & 13.8 & 11.2 & 19.5 & 21.8 \\
\hline \multicolumn{10}{|l|}{ Share from: } \\
\hline Agriculture & $11 \%$ & $13 \%$ & $10 \%$ & $10 \%$ & $12 \%$ & $14 \%$ & $20 \%$ & $19 \%$ & $26 \%$ \\
\hline Forest products & $2 \%$ & $2 \%$ & $0 \%$ & $1 \%$ & $0 \%$ & $2 \%$ & $0 \%$ & $0 \%$ & $0 \%$ \\
\hline $\begin{array}{l}\text { Timber, plantation, } \\
\text { and mining jobs }\end{array}$ & $37 \%$ & $24 \%$ & $54 \%$ & $57 \%$ & $57 \%$ & $16 \%$ & $5 \%$ & $37 \%$ & $34 \%$ \\
\hline Civil service jobs & $11 \%$ & $12 \%$ & $2 \%$ & $3 \%$ & $3 \%$ & $10 \%$ & $3 \%$ & $3 \%$ & $3 \%$ \\
\hline Trade and service & $39 \%$ & $49 \%$ & $34 \%$ & $30 \%$ & $28 \%$ & $58 \%$ & $71 \%$ & $41 \%$ & $37 \%$ \\
\hline Timber fees & $0 \%$ & $0 \%$ & $0 \%$ & $0 \%$ & $0 \%$ & $0 \%$ & $0 \%$ & $0 \%$ & $0 \%$ \\
\hline
\end{tabular}


palm scenarios) would range between US\$25-50 million/year. This is probably beyond most budgets for conservation. The difficulty of securing biodiversity payments is illustrated by Wunder et al. (2004).

Carbon (C) PES may have the highest potential for influencing district decisions regarding forest conversion. For $\mathrm{C}$ payments to provide the district (i.e., excluding household income considerations) with the same level of district income as scenario 4, an average yearly payment of IDR 27 billion would be needed (about US\$3 million/year). According to de Bruijn (2005), the C content of 1 ha primary forest is roughly 300 ton $\mathrm{C} / \mathrm{ha}$, whereas the $\mathrm{C}$ content for oil palm is 50-125 ton $\mathrm{C} / \mathrm{ha}$. A modest estimate of the amount of $\mathrm{C}$ to be saved from being emitted if the forest is not converted to oil palm plantation is thus 175 ton $\mathrm{C} / \mathrm{ha}$, equivalent to 647 ton $\mathrm{CO}_{2} / \mathrm{ha}$ (assuming it is mostly primary forest that is lost). For a total 500000 ha of primary forest that would be lost in the plantation development scenario, it would be possible to recoup the foregone district income with a $\mathrm{C}$ payment, as, at US\$2/ton $\mathrm{CO}_{2}$, in excess of $\$ 15$ million/year could be generated if the payments were structured over 40 years. Karky (2006:14) mentions a "conservative price assumption" of US\$2/ton $\mathrm{CO}_{2}$ on the Clean Development Mechanism (CDM) market. Avoided deforestation is not currently part of the CDM, so the price would probably be lower, but others talk of vastly higher prices in the future. Transaction costs on avoided deforestation would be high. For example, an elaborate monitoring system would need to be established to check compliance, but even then it is possible that $C$ could compete with oil palm for district income. This PES scenario would not lead to jobs and higher economic development in the district. PES scenarios whereby some money is paid directly to communities would also need to be explored.

\section{Can Ecotourism and Forest Product Certification Provide an Economic Alternative to Oil Palm Development?}

Approximate calculations indicate that Malinau would have to host $50000-150000$ tourists each year to generate the household income that the oil palm scenarios produce (assuming tourists stay on average 10 days and spend US\$30/day that goes to Malinau households). Malinau has much to offer tourists with its vast intact forest and cultural diversity, but despite 19 years of lobbying by a conservation NGO, Kayan Mentarang National Park registers fewer than 40 tourists a year (Iskandar, pers. comm. 2007). Ecotourism will not be able to compete with oil palm, at least in the foreseeable future. Furthermore, even under the oil palm scenarios, most of the district will remain forested so ecotourism development is not excluded from these scenarios.

Fair trade labels and natural product labels for forest products can increase prices, but not to the extent that would be required if forest products were to compete with plantations as a source of income for districts and households. To compete, incomes from forest products would have to grow at least by fiveto seven-fold. Paz Soldan and Walter (2003) give an example of certified Brazil nuts in Chile, which after certification, had a 1.7-2.2 times higher price.

\section{Conservation and Development Trade-offs}

Malinau district illustrates the tensions that exist between conservation and development, but also illustrates how these trade-offs are perceived differently by the various stakeholders. Malinau, with its vast forests is one of the rainforest biodiversity hotspots of the world (Mittermeier and Bowles 1993), and conservationists are up in arms over the proposed plans for logging and conversion to oil palm (e.g., see Wakker 2006, a study commissioned by Friends of the Earth). Even though the head of government in Malinau is willing to declare the district a "conservation district" (one of three in Indonesia), he sees no conflict between this declaration and his support for large-scale conversion to oil palm. When asked, local people are all in favor of some form of conservation measures being taken (Padmanaba and Sheil 2007), but local people also want the benefits of development (Levang et al. 2007).

Researchers have witnessed massive change in Malinau over the last decade (Sayer and Campbell 2004), and it is conceivable that land-use change is likely to be widespread and accelerating, largely driven by decisions made in the district capital and beyond. And these decisions will inevitably involve logging and plantation development, but perhaps also mining. Allocating primary and secondary forest to plantations and other intensive land uses can be to the benefit of many stakeholders, but it can simultaneously increase poverty for others. The 
behavior of the plantation concessionaires is crucial as to the outcomes for local people. Careful decisions have to be made when selecting companies for land clearing, and contracts have to be watertight so that companies deliver on promises. If companies were to plant oil palm, some local people see the promise of jobs with higher cash incomes. District officials see greater economic activity, more immigrants, and larger district budgets. Migrants from other more populous districts see jobs. Some of the income gets back to the national coffers and the nation's politicians and officials see development occurring, which is a major aspiration. Even with 500000 ha of forest cleared, most of the district would remain under forest at the end of the 40-year simulation period. If this is the case, then, many would argue that plantation development scenarios are not at odds with the district proposal of a conservation district. But such development does have its risks. First, we assumed logging stops after 20 years. Second, we have not factored in fire; if large forest fires enter the system, as happened in 1997-1998 in other parts of Kalimantan, then forest quality could be substantially reduced. Third, with such a large migrant population under the oil palm scenarios, future pressures on the environment (e.g., artisanal gold panning) are likely to increase.

On the basis of economic argument, part of the forest is likely to be converted, although remoteness and poor soil quality may keep plantations out of Malinau for some time. There are social and environmental costs, not captured in the economic argument. For example, Koczberski et al. (2001) and Casson (2002) have both recorded resentment by local people toward migrants with jobs in plantations. In Malinau, this could be more extreme as local people will be quickly outnumbered by migrants. Colchester et al. (2006) report local people's complaints about plantations in other parts of Kalimantan where individual profit seeking has replaced traditions of communality and solidarity. However, Sheil et al. (2006) mention "decision makers prefer to focus on the general rather than the particular," so whether these negative aspects are taken into account when the decision on development is made remains to be seen.

If conservationists don't like the idea of large-scale land-cover change, do they have alternatives for those hungry for development? Certification of forest products and ecotourism alone are not likely to provide incentives to halt forest conversion.
Carbon payments could conceivably bring district benefits as high as those derived from logging and plantations. However, the science and politics of avoided deforestation is poorly developed, and requires urgent and major research investment. Decisions about developing plantations today will not wait for the long process of international negotiation on mechanisms for $\mathrm{C}$ payments.

\section{The Modeling Process}

We reiterate that the model is not meant as a predictive tool - its primary use is to promote dialog about alternative trajectories of change. Like any model, ours makes many assumptions and simplifications. We have endeavored to make these assumptions and simplifications as reasonable as we can, based on the information available to us. Nonetheless, whether our model yields a credible representation of Malinau can be questioned by those who disagree with these choices or who would emphasize unknowns or uncertainties. For example, our model cannot be taken as evidence that 500000 ha of oil palm developments in Malinau will be commercially successful - this would require fieldbased land-suitability evaluations, for example. Furthermore, a more thorough accounting of the impacts in each scenario would require environmental and social impact assessments focused on the specific areas to be planted in light of the specific development plans proposed and the management standards applied-something that we make no claim to have done. We would obviously expect that normal processes of civil society participation should underlie all decision making and that Indonesian laws regarding the changes in the status of land be respected.

The modeling process has already achieved some of its objectives. Debate within CIFOR was generated by the conflicting perspectives on oil palm development: as a source of economic development, and as a cause of forest destruction and negative impacts on forest-dependent people. Some scientists pointed to particular reports that needed to be cited showing the negative impacts of oil palm, and others requested that those references be removed because they were based on advocacy rather than scientific analysis. Very few detailed impact studies are available, and given the increased interest in oil palm for biofuel, research on the social and economic impacts of oil palm is urgently required. 
The discussions at the district level tended to focus on in-migration and $\mathrm{C}$ payments. District officials were exceptionally nervous about the immigration rates that large-scale oil palm plantations would stimulate, as the district is currently dominated by Dayaks (who also hold positions of power) and this could change with high in-migration. The model filled its role as a means to stimulate discussion, and helped officials see some of the potential negative sides of large-scale oil palm development. The model supported policy changes on land use in Malinau, tempered local government's enthusiasm for oil palm (mostly in relation to migration), and spurred their interest in PES schemes as an alternative to oil palm development (Dwi, pers. comm. 2007). The district head requested help in using some of the model outputs at the United Nations Framework Convention on Climate Change in Bali in 2007, so that he could argue the case for avoided deforestation and a $\mathrm{C}$ market. Modeling has demonstrated its power in generating ideas and fostering shared understanding, allowing some of the ramifications of different courses of action to be explored. It also increases transparency in decision making. The model identified a number of areas where further research will be needed if sound landallocation decisions are to be made in Malinau.

Responses to this article can be read online at:

http://www.ecologyandsociety.org/vol12/iss2/art37/responses/

\section{Acknowledgments:}

The authors thank the participants at the workshops and CIFOR scientists who helped build the model and scenarios. For funding, we acknowledge the International Tropical Timber Organisation (ITTO), the Netherlands government, and the European Economic Community.

\section{LITERATURE CITED}

Andrianto, A. 2006. The role of district government in poverty alleviation: case studies in Malinau and West Kutai Districts, East Kalimantan, Indonesia. Center of International Forestry Research (CIFOR), Bogor, Indonesia.
Badan Perencanaan Pembangunan Daerah (Bappeda). 2002. District Planning and Development Agency, unpublished data on Kayan Mentarang National Park Boundaries.

Badan Pusat Statistik (BPD) Malinau.2006. Kabupaten Malinau Dalam Angka. District Statistical Office, unpublished data.

Barr, C., E. Wollenberg, G. Limberg, N. Anau, R. Iwan, M. Sudana, M. Moeliono, and T. Djogo. 2001. Case study 3: the impacts of decentralization on forests and forest-dependent communities in Kabupaten Malinau, East Kalimantan. Case studies on Decentralization and Forests in Indonesia. CIFOR, Bogor, Indonesia.

Basuki, I., and D. Sheil. 2005. Local perspectives of forest landscapes. A preliminary evaluation of land and soils, and their importance in Malinau, East Kalimantan, Indonesia. CIFOR. Bogor. Indonesia.

Casson, A. 2000. The hesitant boom: Indonesia's oil palm sub-sector in an era of economic crisis and political change. CIFOR Occasional Paper 29, CIFOR, Bogor, Indonesia.

Castaño, J., editor.2006. Kalimantan Governor Suspended for Plantation Fraud. Tropical Timber Market Report 11(23):4-5. (online) URL: http://ce coeco.catie.ac.cr/descargas/Dec06a.pdf.

Colchester, M., N. Jiman, M. Andiko, A. Sitait, A. Y. Firdaus, A. Surambo, and H. Pane. 2006. Promised land-palm oil and land acquisition in Indonesia: implications for local communities and indigenous peoples. Forest Peoples Programme, Perkumpulan Sawit Watch, Huma and the World Agroforestry Center, Bogor, Indonesia.

de Bruijn, A. 2005. Carbon dynamics simulation in Malinau Research Forest, Borneo, Indonesia. Thesis, Wageningen University and Research Center, The Netherlands.

Dinas Kehutanan dan Perkebunan Kab. Malinau. 2006. District Forestry and Estates Crops Service, unpublished data.

du Toit, J. T., B. H. Walker, and B. M. Campbell. 2004. Conserving tropical nature: current challenges for ecologists. Trends in Ecology and 
Evolution 19:12-17.

Engel, S., R. Lopez, and C. Palmer. 2006. Community-industry contracting over natural resource use in a context of weak property rights: the case of Indonesia. Environmental and Resource Economics 33(1):73-93. (online) URL: http://www. springerlink.com/content/k44037146p22/.

Food and Agriculture Organization (FAO). 2003. FAO facts and figures, country information: Indonesia forests and the forestry sector. [online] URL: http://www.fao.org/spfs/indonesia/index en. $\underline{\text { asp }}$

Ferraro, P., and A. Kiss. 2002. Direct payments to conserve biodiversity. Science 29:1718-1719.

Gönner, C. 2000. Causes and impacts of forest fires: a case study from East Kalimantan, Indonesia. International Forest Fire News 22:35-40.

High Performance Systems. 1996. STELLA and STELLA research software. High Performance Systems, Inc. Hanover New Hampshire, USA.

Karky, B.S. 2006. Case study 1: Kafley Community Forest, Lamatar, Nepal. Pages 8-15 in D. Murdiyarso and M. Skutsch, editors. Community forest management as a carbon mitigation option. CIFOR, Bogor, Indonesia.

Koczberski, G., G. Curry, and K. Gibson. 2001. Improving productivity of the smallholder oil palm sector in Papua New Guinea: a socio-economic study of the Hoskins and Popondetta schemes. The Australian National University, Canberra, Australia.

Koh, L. P., and D. S. Wilcove. 2007 Cashing in palm oil for conservation. Nature 448:993-994.

Levang, P., E. Dounias, and S. Sitorus. 2005. Out of the forest, out of poverty? Forests, Trees and Livelihoods 15:211-236.

Levang, P., S. Sitorus, and E. Dounias. 2007. City life in the midst of the forest: a Punan huntergatherer's vision of conservation and development. Ecology and Society 12(1): 18. [online] URL: http: //www.ecologyandsociety.org/vol12/iss1/art18.

Lynam, T., F. Bousquet, C. le Page, P. d'Aquino, O. Barreteau, F. Chinembiri, and B. Mombeshora. 2003. Adapting science to adaptive managers: spidergrams, belief models, and multiagent systems modeling. Pages 157-174 in B. M. Campbell and J. A. Sayer. Integrated natural resources management: linking productivity, the environment and development. CABI Publishing, Wallingford, UK.

Lynam, T., R. Cunliffe, D. Sheil, M. Wan, A. Salim, H. Priyadi, and I. Basuki. 2006 Livelihoods, land types and the importance of ecosystem goods and service: developing a predictive understanding of landscape valuation by the Punan Pelancau people of East Kalimantan. CIFOR, Bogor, Indonesia.

Mittermeier, R. A., and I. A. Bowles. 1993. The GEF and biodiversity conservation: lessons to date and recommendations for future actions. Conservation International Policy Papers I. Conservation International, Washington, D.C., USA.

Obidzinski, K., and C. Barr. 2003. Case study 9: the effects of decentralisation on forests and forest industries in Berau District, East Kalimantan Case Studies on Decentralisation and Forests in Indonesia, CIFOR, Bogor, Indonesia.

Padmanaba, M., and D. Sheil. 2007. Finding and promoting a local conservation consensus in a globally important tropical forest landscape. Biodiversity Conservation 16:137-151.

Palmer, C. 2004. The role of collective action in determining the benefits from IPPK logging concessions: a case study from Sekatak, East Kalimantan CIFOR Working Paper 28, Bogor, Indonesia.

Pambudhi, F., B. Belcher, P. Levang, and S. Dewi. 2004. Rattan (Calamus spp.) gardens of Kalimantan: resilience and evolution in a managed non-timber forest product system. Chapter 22 in K. Kusters and B. Belcher. Forest products, livelihoods and conservation: case studies of non-timber forest product systems. Volume 1 - Asia. CIFOR, Bogor, Indonesia.

Paz Soldan, M., and S. Walter. 2003. The impact of certification on the sustainable use of Brazil nut (Bertholletia excelsa) in Bolivia. Food and Agricultural Organisation (FAO), Rome, Italy.

Reinhardt, G., N. Rettenmaier, S. Gärtner, and A. Pastowski. 2007. Rainforest for biofuel? 
Ecological effects of using palm oil as a source of energy. WWF Germany, Frankfurt am Main, Germany. [online] URL: http://www.wwf.de/filead min/fm-wwf/pdf neu/wwf palmoil study english. pdf.

Sargeant, H. J. 2001. Vegetation fires in Sumatra, Indonesia. Oil palm agriculture in the wetlands of Sumatra: destruction or development? European Union Forest Fire Prevention and Control Project with Dinas Kehutanan Propinsi Sumatera Selatan. European Union and Ministry of Forestry, Jakarta, Indonesia.

Sayer, J., and B. Campbell. 2004. The science of sustainable development: local livelihoods and the global environment. Cambridge University Press, Cambridge, UK.

Sheil, D., R. Puri, M. Wan, I. Basuki, M. van Heist, N. Liswanti, Rukmiyati, I. Rachmatika, and I. Samsoedin. 2006. Recognizing local people's priorities for tropical forest biodiversity. Ambio 35(1):17-24.

Susila, W. R. 2004. Contribution of oil palm industry to economic growth and poverty alleviation in Indonesia. Jurnal Litbang Pertanian 23(3):107114.

Tata Guna Hutan Kesepakatan (TGHK). 2002. Forest Land Use Consensus, unpublished data.

Topografi Kodam (TOPDAM). 2004. Military Regional Commands Topography, unpublished data on Malinau Administrative Boundaries.

Wakker, E. 2006 The Kalimantan border oil palm mega-project. Aidenvironment. Commissioned by Friends of the Earth Netherlands and the Swedish Society for Nature Conservation. [online] URL: $\underline{\text { ht }}$ tp://www.orangutans-sos.org/downloads/ palm oil mega project.pdf.

Wunder, S., B. Campbell, R. Iwan, J. A. Sayer, and L. Wollenberg. 2004. When donors get cold feet: the community conservation concession in Setulang (Kalimantan, Indonesia) that never happened. CIFOR, Bogor, Indonesia. 